\title{
Description of a small dsRNA virus from freshwater crayfish Cherax quadricarinatus
}

\author{
Brett Edgerton, Leigh Owens, Brett Glasson, Steve De Beer
}

Department of Biomedical and Tropical Veterinary Sciences, PO James Cook University of North Queensland, Townsville, Queensland 4811, Australia

\begin{abstract}
A unique hepatopancreocyte nuclear pathology was seen during a histological survey of farmed crayfish Cherax quadricarinatus. Later, the pathology was associated with mortalities in laboratory-held juvenile populations. Affected nuclei were variably hypertrophic, had marginated and clumped chromatin and were almost fully occupied by numerous amorphous inclusions in late infections. Well-developed inclusions were intensely purple-red whilst less-developed inclusions were eosinophilic with H\&E. The nucleolus remained identifiable and centrally located. Embryonic (E) cells were the only hepatopancreocyte type that did not display the changes. Crayfish from all 7 farms surveyed were infected, with a maximum prevalence of $52.3 \%$. The intensity was extremely low in adult crayfish. The inclusions were present in 10 of 14 crayfish families used in a heritability study. Mortalities varied greatly, with the highest mortality being $85 \%$ by Week 8 . Moribund crayfish consistently displayed a high intensity of affected nuclei. Affected nuclei were Feulgen and methyl-green negative, pyronin positive and fluoresced yellow-green with acridine orange, suggesting the pathology was associated with a double-stranded RNA virus. Nuclease digestion of the histological material confirmed the predominance of dsRNA in the inclusions. Transmission electron microscopy revealed $25 \mathrm{~nm}$ virions in highly ordered intranuclear paracrystalline arrays, a feature apparently unique amongst the RNA viruses. The virus is morphologically and morphogenically similar to Giardia lamblia virus and is therefore named Cherax Giardiavirus-like virus.
\end{abstract}

KEY WORDS: Crayfish · Virus · Aquaculture

\section{INTRODUCTION}

Viruses, together with other infectious agents, have caused major mortalities in the last decade of prawn aquaculture (Lightner et al. 1991). A total of 10 viruses have been described from penaeid hosts. Thus, viruses have been shown to be common and of importance to crustacean aquaculture.

The semi-intensive culturing of freshwater crayfish is a relatively new but developing industry in Australia. Until recently, little was known of the disease status of Australian freshwater crayfish. Anderson \& Prior (1992) described Cherax baculovirus (CBV) which causes subclinical disease in Cherax quadricarinatus. $\mathrm{CBV}$ was the first natural viral infection of a freshwater crayfish. Infectious pancreatic necrosis virus (IPNV), the cause of severe disease in salmonid culture, causes a chronic infection in experimentally infected Astacus astacus and therefore may naturally infect this host, but there was no evidence of viral replication (Halder \& Ahne 1988).

During a histological survey of farmed Cherax quadricarinatus in north Queensland, Australia, a nuclear pathology quite distinct from that of $\mathrm{CBV}$ was seen. Following this discovery, the same pathology was associated with mortalities of juvenile crayfish held in experimental aquaria. This paper describes the condition and the causative agent.

\section{MATERIALS AND METHODS}

Forty-four crayfish Cherax quadricarinatus were collected from each of 6 farms in north Queensland in mid- to late 1992. This level of sampling was statistically defined in order to detect a disease in $5 \%$ of 
specimens with a $90 \%$ confidence level assuming a population size of 10000 (Cannon \& Roe 1982). From an additional farm only 17 crayfish were collected. Crayfish were either sacrificed on the day of collection or purged for 2 to $3 \mathrm{~d}$ prior to fixation to remove problematical gut contents. Crayfish were examined macroscopically, and then sacrificed by severing the cephalothorax from the tail and the cephalothorax was split longitudinally. The cephalothorax was preserved in Bouin's fluid.

For the purposes of a heritability study, which examined growth parameters, 14 brooding females were placed individually in 601 opaque plastic bins with ample aeration, internal charcoal and wool filters and sufficient fine plastic mesh to decrease juvenile interaction. Sixty juveniles were retained in each bin once all juveniles were independent of the mother. Juvenile crayfish were fed daily on crushed pellets. One-third of the water was exchanged and excess food was removed each week. Thirty juvenile crayfish were sampled weekly in order to determine their weight and length. Survival in each bin was also ascertained at this time. Moribund crayfish were fixed when detected. AddiLionally, 5 crayfish from each brood were examined at the completion of the experiment. Crayfish were fixed whole or split longitudinally and fixed in Bouin's or Carnoy's fluid.

Either full longitudinal sections or sections of hepatopancreas, mid-gut, heart, antennal gland, muscle, gill, eye and exoskeleton were prepared and stained by conventional techniques (Culling et al. 1985). Initially, sections were stained with haematoxylin and eosin (H\&E). Subsequent stains included Brown and Brenn's Gram stain, phloxine and tartrazine, Feulgen's, methyl-green pyronin and acridine orange with fluorescent microscopy. Histological slides were examined using an Olympus EC microscope. Fluorescent microscopy was carried out on a Leitz Orthoplan microscope.

Enzymatic digestion of Carnoy's fixed histological sections, adapted from Thompson (1966), was used to corroborate the primary histological findings. Deparaffinised rehydrated sections were treated with $1 \mu \mathrm{lml}^{-1}$ of Ribonuclease (RNase) cocktail (Ambion), containing $1 \mathrm{mg} \mathrm{ml}^{-1}$ RNase $A$ and $20000 \mathrm{U} \mathrm{ml}^{-1}$ RNase $T_{1}$, or $0.67 \mu \mathrm{lml} \mathrm{ml}^{-1}$ RNase $V_{1}$ (United States Biochemical Corporation), or $10 \mu \mathrm{g} \mathrm{ml}^{-1}$ of Deoxyribonuclease (DNase) 1 (Sigma Aldrich), in Tris buffer with appropriate co-factors. Other sections were treated with the Tris buffer as a control. The DNase digestions were incubated at $37^{\circ} \mathrm{C}$ for $4 \mathrm{~h}$ whilst the RNase digestions were incubated overnight. The slides were then stained with methyl-green pyronin as usual.

Tissues prepared for electron microscopy were removed from the wax block, deparaffinised and placed in several changes of xylene over $3 \mathrm{~h}$. A hydration series was carried out using 2 washes in $100 \%$ ethanol (ETOH), followed by washes in 95, 70, 50 and $30 \%$ ETOH for 2 min each. The tissue was washed twice in sodium cacodylate buffer for $10 \mathrm{~min}$, and fixed in $1 \%$ osmium tetroxide for $1 \mathrm{~h}$ at room temperature. The tissue was then rewashed twice in sodium cacodylate buffer for $10 \mathrm{~min}$, and dehydrated in a series of alcohols of concentration 50,70,90,95 and then 3 times in $100 \%$ for $2 \mathrm{~min}$ each. Evaporative infiltration was carried out overnight in $1: 1$ absolute alcohol with Spurr resin. The tissue was embedded in fresh resin and polymerised overnight at $70^{\circ} \mathrm{C}$. Toluidine-blue stained sections $(1 \mu \mathrm{g})$ were prepared in order to detect infected nuclei. Once an infected nucleus was detected on the larger $1 \mu \mathrm{m}$ block face, the block was trimmed further and sectioned at $50 \mathrm{~nm}$ on a Nova LKB $\mathrm{V}$ ultratome. Thin sections were mounted on 200 Hex copper grids and stained with saturated uranyl acetate in $50 \%$ ETOH for $7 \mathrm{~min}$ and lead citrate for $1.5 \mathrm{~min}$. Thin sections were scanned using a Jeol 2000FX transmission electron microscope (TEM).

Fresh hepatopancreatic tissue from the heritability study was preserved in $2.5 \%$ gluteraldehyde for $1 \mathrm{~h}$, washed iwice for 10 min and slored al $4{ }^{\circ} \mathrm{C}$ in cacodylate buffer. Glutaraldehyde-fixed tissue was then postfixed, dehydrated, embedded and infected nuclei were detected and examined as for the deparaffinised material.

\section{RESULTS}

\section{Histopathology}

By light microscopy, infection was seen only in the hepatopancreocytes, and most commonly within the resorptive (R) cells, with fibrillar $(\mathrm{F})$ and blister (B) cells less commonly infected. Infection of embryonic (E) cells was not detected. Affected nuclei were most commonly mildly hypertrophic (Fig. 1), with a minor proportion either nonhypertrophic or markedly hypertrophic. Infected nuclei, including those markedly hypertrophic, maintained their spherical shape. Amorphous inclusions were conspicuous within infected nuclei and stained variably with $H \& E$. Smaller inclusions, present in fewer numbers and presumably representing an early stage of infection, were eosinophilic. Larger inclusions occupied the majority of the nucleoplasm (Fig. 2a) and stained intensely purplered. Inclusions also stained variably with Gram stain, were phloxine negative, were DNA negative by the Feulgen and methyl-green reactions, and RNA positive by being intensely pyroninophilic. They fluoresced yellow-green when stained by acridine orange, indicating the presence of double-stranded nucleic acid 
Fig. 1 Cherax Giardiavirus-like virus (CGV). Cells displaying typical CGV nuclear pathology (arrowheads). Note the general lack of marked hypertrophy, and the amorphous, rounded inclusions within a chromatic rim. $\mathrm{H} \& \mathrm{E}$. (a) Longitudinal section of hepatopancreatic tubule displaying a line of infected neighbouring cells. $315 \times$, scale bar $=$ $32 \mu \mathrm{m}$. (b) Cross section of a heavily infected tubule. $250 \times$, scale bar $=40 \mu \mathrm{m}$

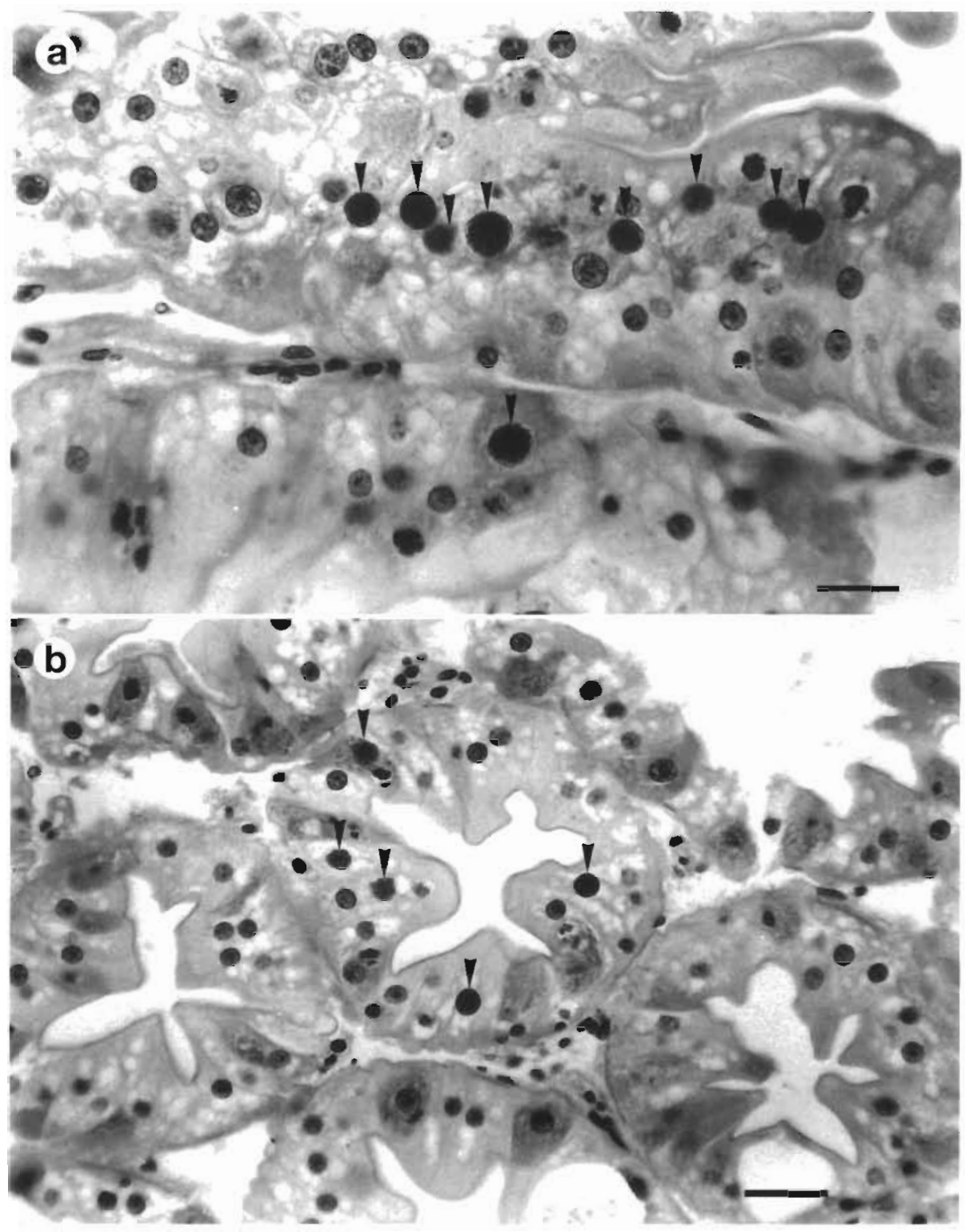

(Hsiung 1973). Gram stain was most effective in resolving separate inclusions (Fig. 2b). Chromatin was displaced peripherally by the developing inclusion, forming a rim within the nuclear membrane. Chromatin often served to accentuate the shape of individual inclusions by bordering them or was compressed into balls between inclusions. The nucleolus typically remained central within the nucleus, rarely being displaced, and remained identifiable and apparently unaltered through all stages of infection. A clearing between the nucleolus and the inclusions was often evident. A thin halo separating the inclusions from the chromatic rim was occasionally evident and was presumed to be due to fixation.

In surveyed crayfish, an infection most often consisted of only a few infected nuclei in a hepatopancre- atic section. In 2 individuals, infected neighbouring cells were evident in longitudinally sectioned tubules (Fig. 1a), and infected nuclei commonly accounted for nearly $50 \%$ of nuclei within a cross-sectioned hepatopancreatic tubule (Fig. 1b). Necrosis of hepatopancreatic tubules did not occur even in those most heavily infected. The unique nuclear pathology was prevalent in all 7 farms surveyed, with prevalence ranging from 6.8 to $52.3 \%$. Infected crayfish exhibited no clinical signs of infection. Other syndromes found in the survey will be presented elsewhere.

The intensity of infection was far greater in the juvenile crayfish used in the heritability study. The requirements of the heritability study did not allow thorough sampling of the crayfish before the completion of the study. Moribund crayfish sampled during 

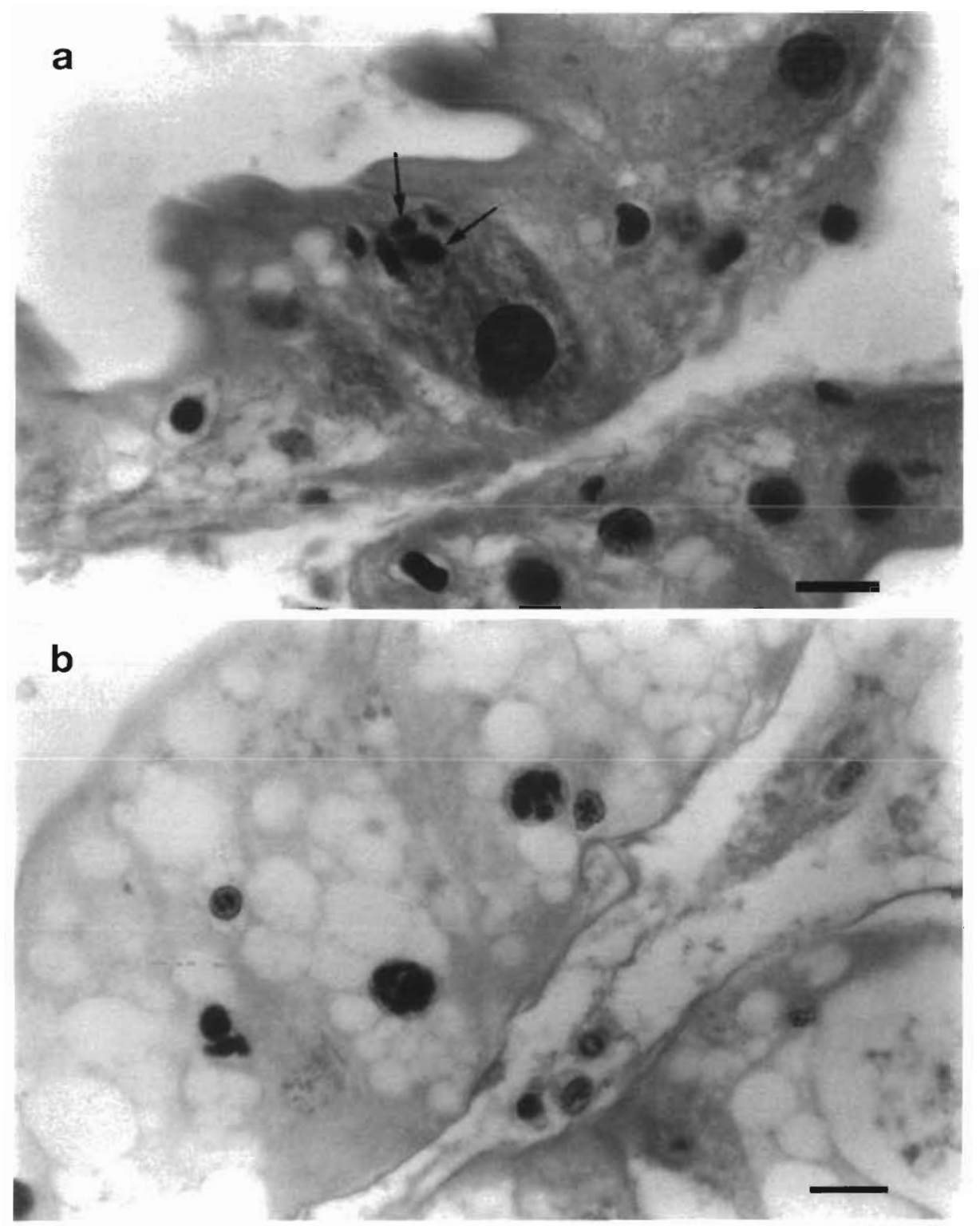

Fig. 2. Cherax Giardiavirus-like virus (CGV). Nuclei infected with (a) fibrillar cell ( $\mathrm{F}$ cell) nucleus displaying typical CGV pathology. Note central haloed nucleolus and the iron granules in the supranuclear vacuole (arrows). H\&E, 625 $\times$, scale bar $=$ $16 \mu \mathrm{m}$. (b) Several CGV-infected cells displaying numerous large, rounded intranuclear inclusions. Gram stain, $625 x$, scale $\mathrm{bar}=16 \mu \mathrm{m}$ the high-mortality phase typically exhibited high intensity of infection, whilst those sampled at the completion of the experiment typically displayed a Iower intensity.

Crayfish broods used in the heritability study were grouped into noninfected, light infection (less than 3 infected out of 5) and heavy infection (3 or more infected out of 5). Graphically, the cumulative mortalities of each group appeared to show distinct trends, with a constantly higher mortality in the heavily infected group, and a cumulative mortality for the lightly infected group constantly between those of the heavily infected and noninfected groups (Fig. 3). However, the groups did not have a significantly different mortality rate $(F=0.16$, $\mathrm{df}=2,11$, $\mathrm{p}>0.05$ ).

\section{Nuclease digestion of histological sections}

The staining of controls was consistent with previous material. The DNase treated sections were completely devoid of methyl-green staining material, whilst the inclusions were not digested and remained pyroninophilic. Following treatment with the RNase cocktail, nucleoli (which contain RNA) and the inclusions stained pyroninophilic, but only slightly less intensely. The inclusions were completely digested by the RNase $V_{1}$ treatment. The viral inclusion's lack of digestion with DNase confirms that it does not consist of DNA. The inclusion's partial digestion with RNase cocktail of RNase $A$ and RNase $T_{1}$, which predominantly cut singlestranded RNA (United States Biochemical Corporation 1992), and complete digestion with RNase $V_{1}$, which 


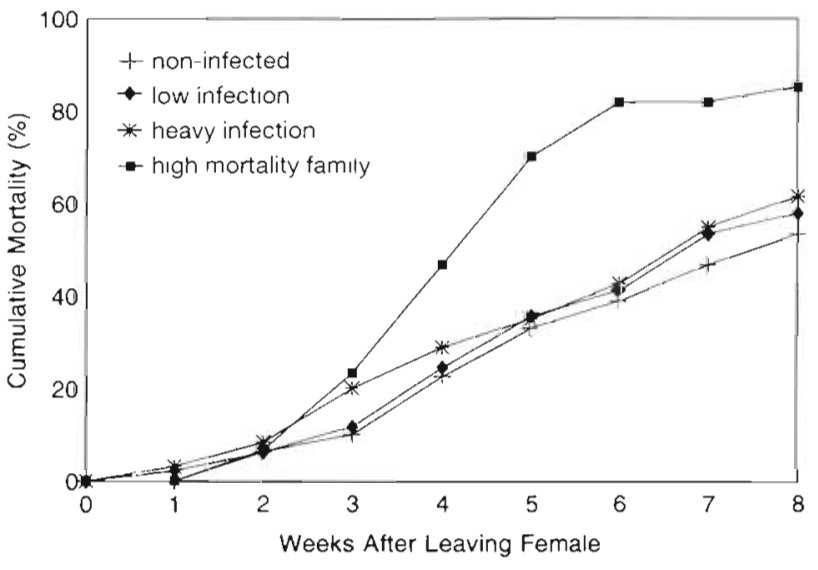

Fig. 3. Cherax Giardiavirus-like virus (CGV). Cumulative mortalities of juvenile $C$. quadricarinatus. The family which experienced the highest mortality is included for comparison

cuts double-stranded RNA, suggests that the inclusions consist predominantly of double-stranded RNA.

\section{Electron microscopy}

Virogenic arrays occupied much (Fig. 4a) or nearly all (Fig. 4b) of the nucleoplasm in early-and late-stage infections respectively, and could be clearly separated into distinct inclusions. Chromatin accumulated peripherally, and was also clumped between virogenic arrays. The nucleolus remained distinctly separate from the virogenic inclusions and was centrally located in the late-stage infection. The nucleolus appeared unaltered by the infection. Individual virions in the virogenic array were clearly discernible at $25000 x$ magnification (Fig. 5). The electron-dense, naked virions were approximately $25 \mathrm{~nm}$ in cross section (Fig. 6), some virions were clearly hexagonal and others pentagonal, suggesting an icosahedral shape. Many sectioned virions clearly consisted of an electron-dense nucleoprotein core (of $20 \mathrm{~nm}$ diameter) and a more electron-lucent capsid.

\section{DISCUSSION}

The virus displays several morphological and morphogenic similarities to Giardia lamblia virus (GLV), a virus tentatively placed in the family Totiviridae (Francki et al. 1991). Similarities include production of small, nonenveloped virus particles, containing double-stranded RNA, which accumulate in the nucleus (Table 1). However, GLV is larger, $33 \mathrm{~nm}$ diameter (Wang \& Wang 1986), whilst the present virus is $25 \mathrm{~nm}$. The present virus differs further by producing vast numbers of virions which form extensive paracrystalline arrays whilst GLV does not (Wang \& Wang 1986). The intranuclear formation of mature RNAcontaining virions is apparently unique to GLV and this virus (Table 1). Based on the presence of intranuclear,
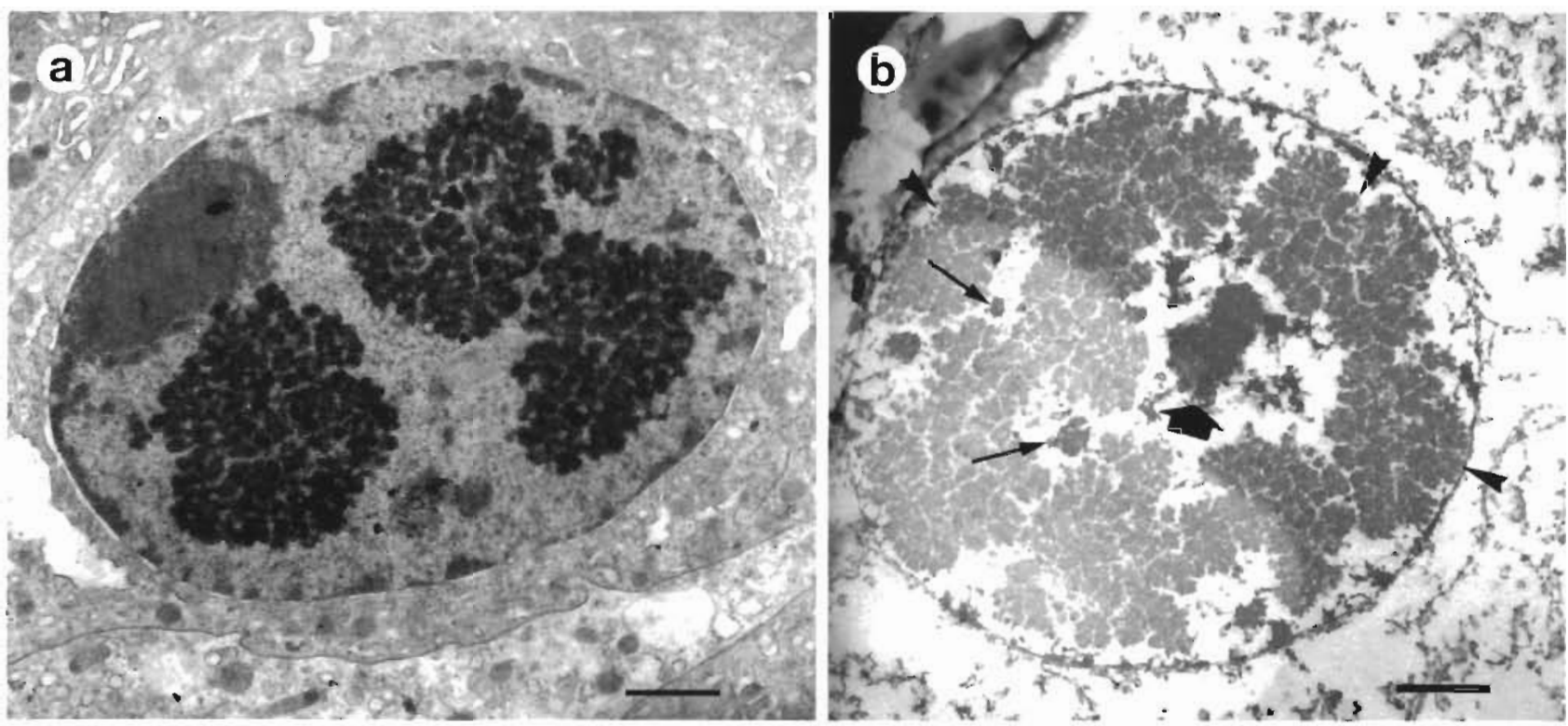

Fig. 4. Cherax Giardiavirus-like virus (CGV). Transmission electron micrograph of CGV-infected nuclei. (a) Early infection. Note the distinct viral inclusions and marginated chromatin. Uranyl acetate, $4100 \times$, scale bar $=2.44 \mu \mathrm{m}$. (b) Late infection. Note the central nucleolus (large arrow) and clumps of chromatin (small arrows) between distinct viral inclusions (arrow heads). Uranyl acetate, $5000 \times$, scale bar $=2 \mu \mathrm{m}$ 


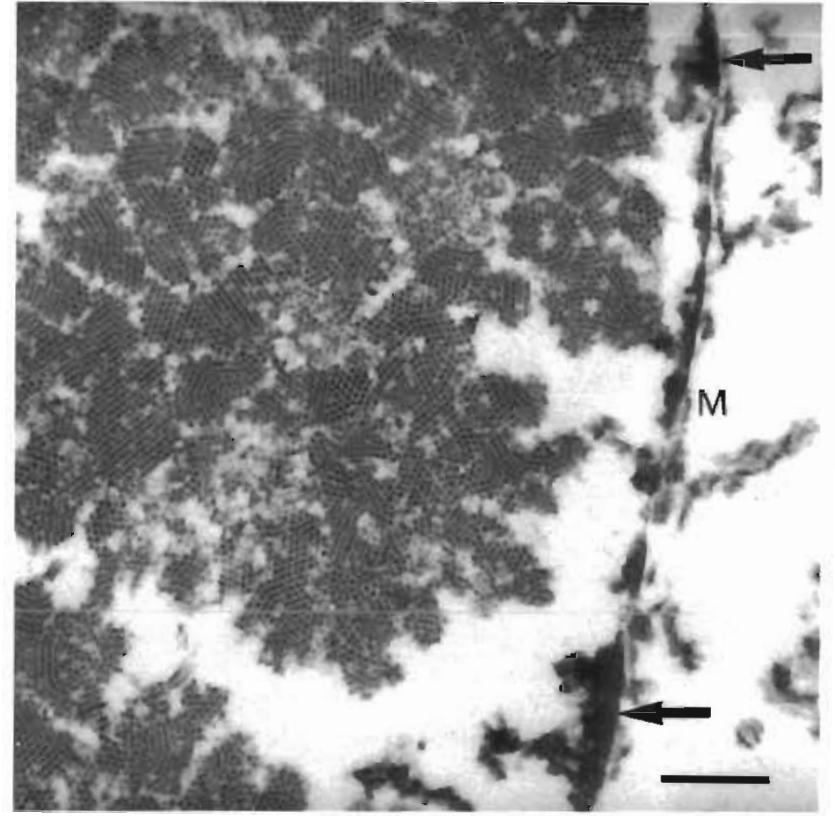

Fig. 5. Cherax Giardiavirus-like virus (CGV). Highly ordered paracrystalline array of CGV. Note the clumps of chromatin (arrows) at the nuclear membrane (M). Uranyl acetate, $25000 \times$, scale bar $=400 \mathrm{~nm}$ double-stranded RNA virus, we have named the virus Cherax Giardiavirus-like virus (CGV), a probable member of the Totiviridae. This is the first member of the family found in a metazoan host rather than in protozoan hosts.

A number of RNA viruses of insects are similar to this virus but differ significantly in certain important features. These viruses replicate in the cytoplasm and contain a single-stranded RNA genome and are hence probable members of the Picornaviridae (Francki et al. 1991). The current virus also differs from the reoviruses described from penaeids (Tsing \& Bonami 1987, Nash et al. 1988) by its formation of intranuclear viral arrays and the smaller virion size, however tissue tropism is similar. Lymphoid organ vacuolisation virus, a togavirus of peñaeids (Buñami et al. 1992), is smâller than the reoviruses, though still larger than CGV (Table 1), and occasionally forms intracytoplasmic arrays in lymphoid organ cells.

Parvoviruses are also small (usually 20 to $25 \mathrm{~nm}$ ) nonenveloped viruses that form intranuclear viral inclusions, but contain DNA. CGV also displays a similar tissue tropism to hepatopancreatic parvo-like virus (HPV) of penaeid prawns. HPV infects E cells of the hepatopancreas (Lightner \& Redman 1985) probably

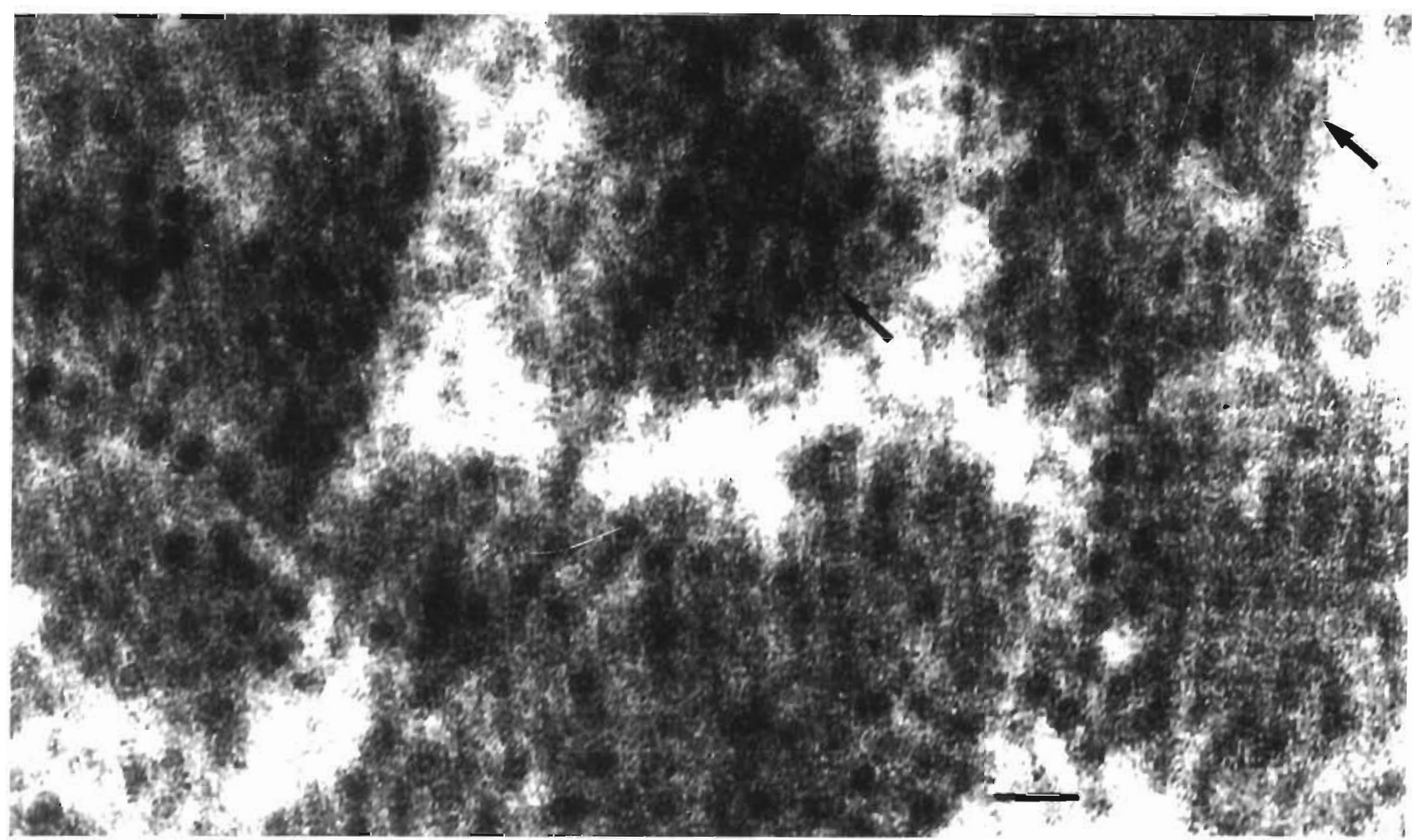

Fig. 6. Cherax Giardiavirus-like virus (CGV). Nonenveloped CGV virions. An electron-dense core (diameter $20 \mathrm{~nm}$ ) with a more electron-lucent capsid is clearly visible in many vinons. Several virions are clearly hexagonal (arrows). Uranyl acetate, $200000 \times$, scale bar $=50 \mathrm{~nm}$ 
Table 1. Cherax Giardiavirus-like virus. Morphologic and morphogenic characteristics and comparisons with similar viruses GLV: Giardia lamblia virus; CGV: Cherax Giardiavirus-like virus; LOVV: lymphoid organ vacuolisation virus

\begin{tabular}{|lcccccc|}
\hline Virus & $\begin{array}{c}\text { Nucleic } \\
\text { acid }\end{array}$ & $\begin{array}{c}\text { Virion size } \\
\text { (nm) }\end{array}$ & $\begin{array}{c}\text { Virion } \\
\text { enveloped }\end{array}$ & Virion shape & $\begin{array}{c}\text { Virions intranuclearf } \\
\text { form arrays }\end{array}$ & Known hosts \\
\hline Parvovirus & ssDNA & $18-25$ & No & Icosahedral & Yes/yes & Vertebrates, insects, \\
Picornavirus & ssRNA & $22-30$ & No & Icosahedral & No/yes & Vertebrates, insects \\
LOVV & SSRNA & $52-54$ & Yes & Icosahedral & No/yes & Penaeids \\
Totivirus & dsRNA & $40-43$ & No & Isometric & No/yes & Fungi \\
GLV & dsRNA & 33 & No & Isometric & Yes/no & Giardialamblia \\
CGV & dsRNA & 25 & No & Icosahedral & Yes/yes & Cherax quadricarinatus \\
Reovirus & dsRNA & $60-80$ & No & Icosahedral & No/yes & Vertebrates, insects, \\
& & & & & & crustaceans, molluscs, plants \\
\hline
\end{tabular}

because parvoviruses need rapidly dividing cells whilst CGV never infects E cells. The nucleolus is not as close to the virogenic arrays of CGV as in HPV infection. Further dissimilarities with HPV occur in that CGV always forms paracrystalline arrays, in several distinct inclusions which surround the nucleolus and restrict it to the centre of the nucleus. In contrast, HPV only occasionally forms arrays, typically forming only 1 intranuclear inclusion which displaces the nucleolus peripherally (Lightner \& Redman 1985). CGV most commonly causes only mild hypertrophy of the nucleus, whereas HPV typically induces marked hypertrophy of the nucleus (Lightner \& Redman 1985).

The discovery of CGV has implications with regard to the aquaculture of freshwater crayfish. Cherax baculovirus was initially described as nonpathogenic (Anderson \& Prior 1992) but has caused mortalities in crayfish culture when coupled with bacteraemia (B. Edgerton $\&$ L. Owens unpubl.). CGV was also prevalent in these populations, but did not appear advantaged by the presence of other pathogens in the crayfish. However, crayfish from a farm displaying a $25 \%$ prevalence of CGV held in aquaria typically undergo chronic lowgrade mortalities. No other pathology was seen in material collected from this farm during the survey. However, the relationship of these mortalities to CGV is difficult to ascertain. The pathogenicity of CGV to Cherax quadricarinatus of different ages and also to different Cherax species is hence a topic of ongoing research.

CGV is the first small dsRNA virus described from a crustacean host and the second naturally occurring virus in a freshwater crayfish. Its morphology and intranuclear position suggest that CGV is more closely related to GLV than to other similar viruses that have been described.

Acknowledgements. This research was supported by James Cook University, grant No. R-MRG-4473.

\section{LITERATURE CITED}

Anderson, I. G., Prior, H. C. (1992). Baculovirus infections in the mud crab, Scylla serrata, and a freshwater crayfish, Cherax quadricarinatus, from Australia. J. Invertebr. Pathol. 60: 265-273

Bonami, J. R., Lightner, D. V., Redman, R. M., Poulos, B. T (1992). Partial characterization of a togavirus (LOVV) associated with histopathological changes of the lymphoid organ of penaeid shrimps. Dis. aquat. Org. 14: 145-152

Cannon, R. M., Roe, R. T. (1982). Livestock disease surveys: a field manual for veterinarians. Australian Government Publishing Service, Canberra

Culling, C. F. A., Allison, R. T., Barr, W. T. (1985). Cellular pathology techniques, 4 th edn. Butterworths, London

Francki, R. 1. B., Fauquet, C. M., Knudson, D. L., Brown, F. (1991). Classification and nomenclature of viruses. Arch. Virol. (Suppl. 2)

Halder, M., Ahne, W. (1988). Freshwater crayfish Astacus astacus - a vector for infectious pancreatic necrosis virus (IPNV). Dis aquat. Org. 4: 205-209

Hsiung, G. D. (1973). Diagnostic virology, an illustrated handbook, Revised edn. Yale University Press, London

Lightner, D. V., Bell, T. A., Redman, R. M., Mohney, L. L., Natividad, J. M., Rukyani, A., Poernomo, A. (1991). A review of some major diseases of economic significance in penaeid prawns/shrimps of the Americas and Indopacific. In: Shariff, M., Subasinghe, R. P., Arthur, J. R. (eds.) Diseases in Asian aquaculture, Vol. 1. Fish Health Section, Asian Fisheries Society, Manila, p. 57-80

Lightner, D. V., Redman, R. M. (1985). A parvo-like virus disease of penaeid shrimp. J. Invertebr. Pathol. 45: 47-53

Nash, M., Nash, G., Anderson, I. G., Shariff, M. (1988). A reolike virus observed in the tiger prawn, Penaeus monodon Fabricus, from Malaysia. J. Fish Dis. 11: 531-535

Thompson, S. W. (1966). Selected histochemical and histopathological methods. Charles C. Thomas Publisher, Springfield

Tsing, A., Bonami, J.-R. (1987). A new viral disease of the tiger shrimp, Penaeus japonicus Bate. J. Fish Dis. 10: 139-141

United States Biochemical Corporation (1992). USB molecular biology reagents / protocols 1992. United States Biochemical Corporation, Cleveland

Wang, A. L., Wang, C. C. (1986). Discovery of a specific double-stranded RNA virus in Giardia lamblia. Mol. Biochem. Parasitol. 21: 269-276

Manuscript first received: May 27, 1993

Revised version accepted: October 25, 1993
Responsible Subject Editor: J. E. Stewart, Dartmouth, N.S., Canada 